\title{
The Land Use in Turkey: A General Assessment and Affecting Factors
}

\author{
A. Ahmet Yücer \\ General Directorate of Agricultural Research and Policy, Ankara, Turkey \\ Email: ayucer06@gmail.com
}

How to cite this paper: Ahmet Yücer, A. (2020). The Land Use in Turkey: A General Assessment and Affecting Factors. Journal of Geoscience and Environment Protection, $8,102-116$.

https://doi.org/10.4236/gep.2020.810007

Received: September 5, 2020

Accepted: October 16, 2020

Published: October 19, 2020

Copyright $\odot 2020$ by author(s) and Scientific Research Publishing Inc. This work is licensed under the Creative Commons Attribution International License (CC BY 4.0).

http://creativecommons.org/licenses/by/4.0/ (c) (i) Open Access

\begin{abstract}
Discussions related to land use in Turkey in recent years has been increasing. These discussions are mostly between those who want to protect the natural environment and those who demand other sectoral investment areas. However, there has not been a comprehensive and holistic study assessment of the land use, except for local studies. For this reason, the present study has been conducted in order to reveal the change in land use in the country's geography. In order to achieve the aims of the study, the literature was reviewed, institutional data were compiled, and the results of previous local studies were evaluated using appropriate methods. Factors affecting land use were examined in the study and it was seen from the findings that significant land use changes occurred in the last 75 years. Although land use suitable for natural structure was common in advance, after the 1980s sectoral needs came to the fore. With the accelerated urbanization and industrialization, tourism, mining and dam areas have become widespread. It has been determined that there is a need for new scientific studies on land use, revision of ineffective laws, and national land use plans that take into account the sectoral needs in order to reduce the discussions.
\end{abstract}

\section{Keywords}

Land Use, Natural Structure, Legislation, Population, Mechanization

\section{Introduction}

Land and human beings are the two inseparable elements throughout history. In the beginning, although the land is only the area where the human continues his life activities, how land is used has changed significantly over time due to natural, environmental and economic factors.

Natural structure consisting of soil, topography, climate and vegetation is the 
first and most fundamental factor determining the land use (Grimm et al., 2013; Passioura, 1991). Apart from the natural structure, especially the increasing population, mechanization and legislation significantly affected the land use (Marks, 1962).

Population change has made great impacts on land use around the world. A study conducted in Indonesia revealed that the most important factor affecting land use is access to land and the second factor is population (Prayitno et al., 2018). Migrations, which lead to regional population changes and direct people from poor regions to big cities, also affect land use in countries. In the Czech Republic, it was observed that the increase in the population and the increasing tendencies of the residential areas intersected in the 1950s (Vodvidicova et al., 2013). In many countries, especially Eastern Europe separated from the Soviet Bloc, young people left their rural areas in order to seek new jobs and better education (Bell et al., 2010). In the Scandinavian countries, migratory movements have also taken place from rural areas towards the metropolitan during the 1990s. The major cities expanded and the population living in rural areas significantly decreased (Hoßmann et al., 2008).

Mechanization has also emerged as another factor affecting land use, as the increasing population requires more land to be cultivated for food security. A study conducted in Pakistan found that tractors enabled more virgin land cultivation and expansion of farmland at farm level (Salam, 1981). Therefore, the land use patterns changed, dramatically.

Alterations in the population have forced governments to practice new strategies, policies, some legal regulations to ensure sustainable land use and public benefit. They can set policies, encourages implementation, or imposes restrictions on property rights (Liu \& Liu, 2020). These arrangements can generally aim to protect the natural environment and rural life, ensure food and energy security, or plan residential areas (Luppa et al., 2014). The European Union's common agricultural policy and bioenergy policies can be given as examples. The EU has established rules that minimize the risk of biofuel production on agricultural land leading to the displacement of food or feed crops to previously non-cropland such as grasslands and forests. This process is known as indirect land-use change (European Commission, 2010).

However, while these regulations sometimes achieve their purpose, sometimes they do not provide the expected benefit. Hence, governments made serious modifications in land use right in order to provide food security and production patterns throughout history (Bennettab et al., 2018). They have managed to land use through enacting laws, establishing relevant institutions, and giving incentives, and supports relevant production patterns. The great increases in agricultural production have been achieved with area-based expansion up to the $1980 \mathrm{~s}$ (Verburg et al., 2013).

Turkey has also gone through similar processes and developments in land use issues as many other countries in the world. With its geographical location, dif- 
ferent climate and topography, diverse soil structures, and vegetation; Turkey is an important agriculture-based country in the world, so that the land use evolution in the country has a significant background.

A study regarding change in land use; it has been observed that residential areas and water surfaces have expanded, whereas agricultural areas have narrowed in Turkey. It has been stated that the main reasons behind this are artificial uses such as urbanization, industrialization, tourism, energy and mining (European Environment Agency, 2017).

In studies conducted in different regions regarding land use, the common finding is that the expansion of residential areas has negatively affected the agricultural and pasture areas. Besides, while the agricultural areas narrowed in Çanakkale and Göksun, forest areas expanded (Genç et al., 2013; Reis et al., 2016). While pasture areas decreased in Manisa (Gülersoy, 2013), it expanded in Beykoz (Kara \& Karatepe, 2012). While the water surfaces decreased in Burdur, the agricultural areas expanded (Soyaslan, \& Hapdeniz, 2016), and the agricultural and forest areas decreased in Bolu as the water surfaces expanded (Ekinci \& Pektezel, 2012). In addition to residential areas in Samsun, while industrial areas expanded, agricultural areas decreased (Dengiz \& Turan, 2014). While agriculture, forest and pasture areas decreased while other areas expanded in Seferihisar (Gülersoy, 2014).

In this study, it is aimed to examine and assess the factors affecting land use from past to present. It is also targeted to determine what are the trends and possible effects regarding land use in Turkey.

Unlike previous studies conducted on sub-regions, land use was evaluated on the country basis in this study. Furthermore, the local changes in land use and the possible effects of the general trends on the future were evaluated, and it is to make suggestions to the decision makers about the possible risks that these trends will cause. After all, being the public institutions in the first place; the attention of non-governmental organizations and the community were attracted to the land use issue.

\section{Materials and Methods}

It is important to choose a suitable method when evaluating land use. In the evaluation of more than three criteria for the most appropriate decision making, researchers are recommended to use Multiple Attribute Decision Making (MADM) methods and applications (Hwang \& Kwangsun, 1981). Four main factors affecting land use were examined in the study. Among these factors, there is nothing to argue about the natural structure and legal regulations, which have obvious effects on land use. It has been tried to determine how much these two factors affect land use. However, with the assumption that the population and mechanization effect will differ periodically, correlation analysis has been made between these two factors and land use. The fact that these two factors have concrete and quantitative data also played a role in this preference. 
In this study, the rural population and land use data pertaining to Turkey were obtained from the Turkish Statistical Institute (Turkstat, 2018) and State Water Affairs (DSI, 2015). Then, for the suitable analysis, land use data were divided into two periods as $1945-1980$ and $1980-2017$ by taking the turning points into consideration. The rate of population, forest, pasture, agriculture, and the other land uses have been presented.

In the evaluation of the effects of the legislation, the direction and ratio of the change in land use after the adoption of the legal regulations were also examined. Finally, some research results related to land use carried out in different locations were compiled from the relevant publications and compared and assessed.

\section{Land Use Affecting Factors}

\subsection{Natural Structure}

Turkey is located in the Alpine-Himalayan Orogenic belt and has a rugged topography. The high distribution of this surface area for $1000 \mathrm{~m}$ and higher than $1000 \mathrm{~m}$ Altitudes are $44.1 \%$ and $55.9 \%$, respectively (Atalay, 2016). Turkey is also surrounded by seas on three of its sides. Climate, vegetation, and topography are among the factors affecting the formation and diversity of its soils (Özden et al., 2001).

According to the Land-Capability Classification System (Klingebiel \& Montgomery, 1961), the I-IV classes are suitable for agricultural production, and 26.5 million hectares. Classes V, VI and VII; however, are suitable for pasture, grazing, and forest. All these groups cover about 46.7 million hectares. Class VIII is also steep rocky slopes in the Mountains (Atalay, 2016).

Different climates and irrigation possibility are the two major factors, which affect the land use in all regions, directly. More than any other factor, climate generally controls the distribution of vegetation and plant species. Minimum temperatures limit not only agricultural productions, but also the growth of forest trees (Atalay, 2016). Beside annual precipitation also affect agricultural production and land use (Sykes, 2009). In Turkey, annual precipitation varies between $250 \mathrm{~mm}$ and $2500 \mathrm{~mm}$. In many regions during vegetation; this rainfall is insufficient for plant production. Therefore, irrigation is required, necessarily. The amount of surface irrigable agricultural land is about 8.5 million hectares (DSI, 2015).

The surface area of Turkey is about 77,945 thousand hectares in total. The characteristic distribution rates of this area are as follows; $36 \%$ agriculture, $29.8 \%$ forest, $27.6 \%$ pasture and grassland, and $6.6 \%$ other areas (DSI, 2015). As a result, distribution of land in Turkey is particularly concerned with the topography, growing areas of agricultural products are dependent on the climate and soil characteristics of these products (Özçağlar, 1988). Distribution of land use rates between 1945 and 2017 demonstrated a significant change in terms of the shares of agricultural, pasture, forest, and other lands (Table 1). 
Table 1. Rural population and land use in Turkey between 1945 and 2017 (\%).

\begin{tabular}{cccccc}
\hline Years & Rural Population & Forest Land & Pasture Land & Agriculture Land & Other Land \\
\hline 1945 & 75.00 & 13.55 & 50.19 & 18.85 & 17.41 \\
1950 & 75.02 & 13.37 & 49.54 & 20.54 & 16.56 \\
1960 & 68.02 & 13.58 & 36.77 & 32.49 & 17.16 \\
1970 & 61.54 & 23.44 & 27.58 & 35.07 & 13.9 \\
1980 & 56.09 & 25.91 & 27.16 & 36.15 & 10.78 \\
1990 & 40.98 & 25.91 & 18.19 & 35.74 & 20.16 \\
2000 & 30.00 & 26.56 & 18.47 & 33.84 & 21.13 \\
2010 & 23.73 & 27.63 & 18.75 & 31.3 & 22.32 \\
2017 & 7.48 & 27.81 & 18.75 & 29.99 & 23.45 \\
\hline
\end{tabular}

However, the agricultural land and the pastures decreased in the current land use, whereas the land used for non-agricultural purposes increased too much (Figure 1). Especially, the decrease in agricultural areas reached 4.7 million hectares after the 1980s. This land use is not compatible with the characteristics of country lands (Sykes, 2009; Ekinci \& Pektezel, 2012).

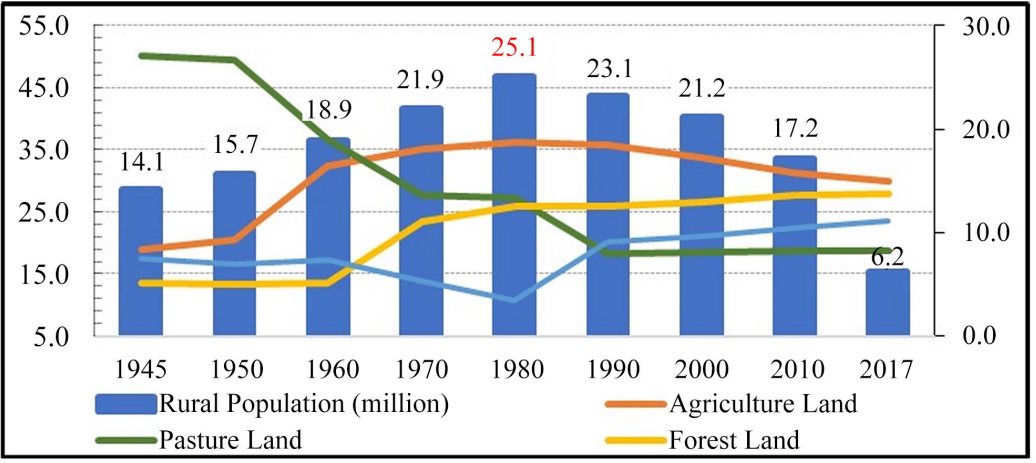

Figure 1. Periodical change in land use between 1945 and 2017 (\%).

\subsection{Rural Population}

According to the census in 1945 about $75 \%$ of people were living in rural areas, but this figure dropped to $7.48 \%$ in 2017 in Turkey. While the rural population was 14.1 million in 1945, it rose up to 25 million in 1980 and dropped back down to 6.2 million in 2017. In the same period, the population of the urban increased from $25 \%$ to $93.8 \%$ (Figure 2).

The rural population movements, such as internal and external migration and population growth rate, seem to have an impact on land use. While the population growth rate in the $1945 \mathrm{~s}$ was $1 \%$, and in the $1960 \mathrm{~s}$ risen to $2.8 \%$, after the $1990 \mathrm{~s}$ it was decreased to $2.1 \%$ below. Rapid population growth increased the demand for agricultural land and resulted in rapid degradation of forests and the 
conversion of forests to agricultural and rangeland areas in rural areas (Göl et al., 2011).

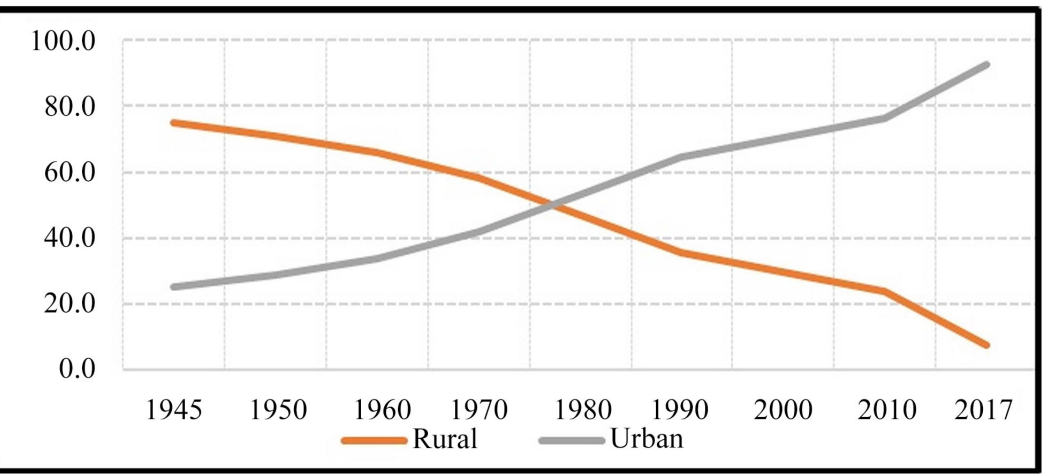

Figure 2. Change of rural and urban population in Turkey (\%).

After the 1980s, due to rapid population growth and rural poverty, domestic migration accelerated. The average age of individuals moving from villages to urban areas was 27. This age level caused the rural population to be comprised of old-aged individuals and families, decreased number of children; thus caused a decline in the workforce in the rural areas (Öztürk et al., 2017). As a natural consequence of this domestic migration from rural to urban areas; total population in the villages, the number of animals and pressure on natural resources reduced, forest quality enhanced, arid and infertile land started to be left out of agriculture (Göl et al., 2011).

\subsection{Mechanization}

Lack of mechanization was the most important factor limiting the number of cultivated lands. Hence, villager's ability to cultivate agricultural areas was not sufficient. However, this ability was changed with the introduction of a number of tractors in Turkey. The tractor-owned farmers not only handled their own lands but also begun to cultivate state-owned lands and pastures as well (Aysu, 2015). Even though it was very slow, increase in owning tractors was accelerated through the implementation of the Marshall Plan.

The use of tractors was initially aimed at expanding agricultural areas rather than labor savings (Öztürk et al., 2017). In this context, the more the number of tractors increased, the more the agricultural land expanded. Therefore, when the number of tractors raised from 31,000 to 436,000 during the period of 1945-1980, the total amount of cultivated land also reached from 14.6 to 24.5 million hectares in 1980. But after 1980, although the increase in the number of tractors continued, the amount of agricultural land has not increased (Turkstat, 2018).

\subsection{Legal Regulations}

Turkey's Constitution is indicated that some regulations may be imposed for the 
public interest, the national economy, and sustainable food security in land-use.

\subsubsection{Soil Protection and Land Use Law}

Soil Protection and Land Use Law was adopted in 2005. The main purpose of the law is to prepare land use plans, to protect and develop agricultural lands. The law divides the used lands into five classes as absolute, special crop, horticulture, marginal agricultural and non-agricultural land, in accordance with their natural characteristics and importance to agriculture (Offical Gazette, July 19, 2005).

The classification system proposed by the law is entirely different from the Land-Capability Classification System (Klingebiel \& Montgomery, 1961), which was used until this law was put in practice.

Some regulations were enacted under the Law. One of them, Agriculture Basins Regulation was published by the Ministry of Agriculture. In order to develop appropriate ecological agricultural production, 941 micro-ecological basins have been identified around Turkey (Offical Gazette, Sep. 07, 2010). Secondly, A Decision on the Designation of Some Plains as Large Plain Conservation Areas has been published by the Council of Ministers. In this context, the Ministry of Agriculture designated 243 large plains to prevent the use of fertile and vast agricultural lands for settlement, tourism, and industrial purposes (Offical Gazette, Jan. 21, 2017). And thirdly, Regulation on the Prevention of Fragmentation of Agricultural Land was published (Yücer et al., 2016).

However, this law could not stop the decline in agricultural areas that began in the 1980s. In contrast to other laws, the law transfers the duty and authority to protect agricultural lands to the commissions to be established in the provinces. These commissions generally obey the demands of politicians and different sectors such as settlement, industry, tourism, and mining.

\subsubsection{Forest Law}

Forest lands are managed via the legislation in Turkey. The Forest Law was put into practice in 1937 (Offical Gazette, Feb. 18, 1937). All forest lands in Turkey were nationalized by the amendment made to the Forest Law in 1945. The government took all necessary measures to protect the forests by the law and established a semi-autonomous institution for their financial needs. The law authorized the General Directorate of Forests with the tasks to protect and develop forests, to determine their borders, and to economically develop forest villagers.

The most important feature of the Forest Law was to provide special protection authorization to enforce the law; in other words, punishments proposed by the law should be given by courts instead of the Government itself, and that a few penalties should be given together with the pecuniary penalty, imprisonment, and etc. In addition, the law does not allow narrowing forest areas. In the period between 1980 and 2017, non-agriculture areas converted into the forest with the seeds spreading technique (Göl et al., 2011). Hence, forest land was continuously increased (105.7\%) from 10.5 to 21.6 million hectares throughout the country (Turkstat, 2018). 


\subsubsection{Pasture Law}

In contrast to increases in the forest and other areas, the rate of pasture land continuously decreased from $50.19 \%$ to $18.75 \%$ among the total areas between 1945 and 1998 (Turkstat, 2018). The main reason for this decline was that there was no law to protect pasture lands. In 1998, with the adoption of pasture law, it was put into practice that the feature of pasture areas should not be changed (Offical Gazette, Feb. 28, 1998).

According to both TURKSTAT and DSI statistical data, it was observed that the most amount of pasture land was transformed into other land use purposes between 1945 and 1998. Due to the decrease in pastureland, livestock was affected negatively, and therefore, Turkey has been dependent on meat imports after 2010. The duty and authority to protect pasture lands have been transferred by the law to the commissions to be established in the provinces similar to the Soil Protection and Land Use Law. Therefore, it was not as effective as Forest Law. However, due to the decrease in the number of livestock in rural areas, pressure on pastures has decreased and in some regions, pasture quality has started to enhance in recent years (Göl et al., 2011).

\subsubsection{Special Regulations for Some Products}

The Turkish government put in to practice some laws in the 1930-1940s years for food security. These laws and relevant institutions directly affected plant patterns and as well as agricultural production. Some examples regarding these issues are summarized below:

After sugar factories were established to meet the sugar needs of the country; sugar beet cultivated areas have been increased from 51,000 to 339,000 hectares. The wheat cultivated areas have been risen up from 2.6 million to 7.7 million hectares after the Turkish Grain Board was established to stock cereal crops and to stabilize their prices. After the Sümerbank was established for cotton production and its industry, cotton production areas have been expanded rapidly from 161,000 to 502,000 hectares. Sugar beet, wheat, and cotton were supported by these institutions and they began to be produced more by villagers so that it led to a change in the pattern of plant and land use.

The law on the rehabilitation of olive tree plantation and the breeding of wild olive trees was put into practice in 1939. It was regulated that olive production areas should not be narrowed down. Therefore, the olive trees have been expanded from 297 hectares to 84,000 hectares (Turkstat, 2018). The Rice Law adopted in 1936, the rice cultivation areas have been increased from 58,000 to 110,000 hectares. The Hazelnut Law adopted in 1983, the hazelnut plantation areas have expanded out of its natural areas since its production has an advantage on its alternative crops. The Tea Law adopted in 1940, envisaged that the tea growing areas should be determined by the Ministry of Agriculture, and its production should be made with the permission of the same Ministry (GTHB, 2018). These special regulations and their effects on land use change can be seen in Table 2. 
Table 2. The effect of some legal regulations on land use.

\begin{tabular}{ccccc}
\hline Regulations & Number & Adaptation date & Direction of change & Rate of change \% \\
\hline Wheat regulation & & 1932 & Positive & 196 \\
Cotton regulation & & 1933 & Positive & 212 \\
Rice areas law & 3039 & 1936 & Positive & 90 \\
Olive trees law & 3573 & 1939 & Positive & 18,000 \\
Forest law & 3116 & 1945 & Positive & 106 \\
Sugar beet regulation & & 1950 & Positive & 565 \\
Hazelnut law & 2844 & 1983 & Positive & 1596 \\
Tea areas law & 3092 & 1940 & Positive & 10,248 \\
Pasture law & 4342 & 1998 & Constant & 0.0 \\
Soil protection law & 5403 & 2005 & Negative & 13.8 \\
\hline
\end{tabular}

\section{Findings and Assessment}

Various studies related to land use in Turkey were carried out by Geographic Information Systems to determine developments at different locations (Figure 3). This section gives brief information about some of the data obtained from these studies and the results.

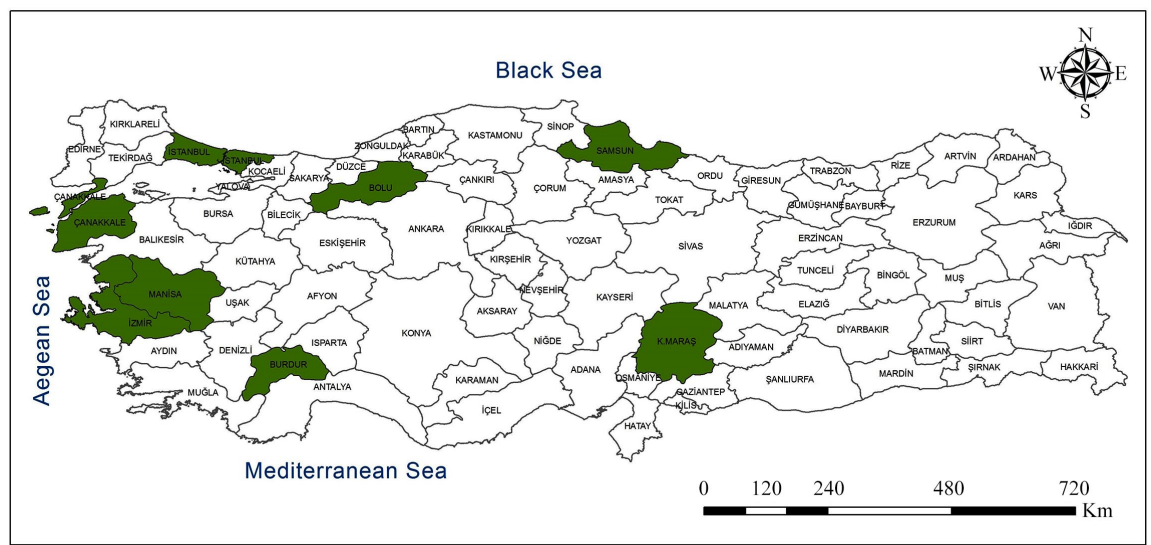

Figure 3. The previous research locations related to study in Turkey.

A total of eight locations were used analyzed in different studies in terms of analyzing their residential, agriculture, forest, and pasture lands and water surface area covering the period between the 1980s and 2010s. This data was compiled and presented in (Genç et al., 2013; Reis et al., 2016; Gülersoy, 2013; Kara \& Karatepe, 2012; Soyaslan \& Hepdeniz, 2016; Ekinci \& Pektezel, 2012; Dengiz \& Turan, 2014; Gülersoy, 2014).

Striking changes and shifts in land use were observed in these studies. In accordance with the general trend, residential areas have increased dramatically to $322.18 \%$ in Samsun. A significant increase of $154.07 \%$ was observed in the water surface due to dam and pond investments in Bolu. Similarly, the 
forest lands were expanded in K.Maraş-Göksun (34.84\%), and Çanakkale (23.32\%), while agricultural lands dramatically decreased in Samsun (71.37\%), Çanakkale (43.42\%), and the pasture lands decreased in Manisa (31.51), and K. Maraş-Göksun (15.43\%).

On the other hand, forest areas have decreased in İstanbul-Beykoz, İzmir-Seferihisar, and Bolu. It is seen that these areas transformed into a residential area. The increase in pasture areas in Beykoz-Istanbul can be explained by a decrease in agricultural areas. In addition, it was observed that agricultural areas were expanded by drying wetlands and marshlands in Burdur and transforming pasture lands in Manisa. It is observed that they lose most of the agricultural lands that are already limited in coastal cities rather than inner cities (Table 3).

Table 3. Land use change according to some research results (1980-2010).

\begin{tabular}{ccccccccc}
\hline $\begin{array}{c}\text { Land Use } \\
\text { Changes (\%) }\end{array}$ & Çanakkale & $\begin{array}{c}\text { Beykoz } \\
\text { İstanbul }\end{array}$ & Bolu & Manisa & Samsun & $\begin{array}{c}\text { Seferihisar } \\
\text { İzmir }\end{array}$ & $\begin{array}{c}\text { Göksun } \\
\text { K.Maraş }\end{array}$ & Burdur \\
\hline Residential & 214.17 & 46.64 & 186.71 & 109.25 & 322.18 & 91.8 & & \\
Agricultural & -43.42 & -30.44 & -0.76 & 64.00 & -71.37 & -18.50 & -8.97 & 46.47 \\
Pasture & & 77.73 & & -31.51 & & -3.42 & -15.43 & -8.97 \\
Forest & 23.32 & -2.89 & -3.92 & 5.97 & 6.23 & -3.83 & 34.84 & -14.99 \\
Water Surface & & 86.43 & 154.07 & & & & & \\
Others Area & 8.16 & & & & 318.23 & & -22.80 & -39.85 \\
\hline
\end{tabular}

Based on TURKSTAT data, a correlation analysis was conducted between the factors predicted to affect land use across the country. According to this analysis, in the 1950-1980 period, a statistically significant, positive and high correlation $(\mathrm{r}=0.801)$ was found between the agricultural land use and the rural population. It is observed that this meaningful correlation $(r=0.749)$ continued in the 1945-2017 period (Table 4).

Table 4. Correlation analysis in the period 1945 and 1980.

\begin{tabular}{|c|c|c|c|c|}
\hline & & $\begin{array}{l}\text { Agricultural Land } \\
\qquad(1000 \mathrm{ha})\end{array}$ & $\begin{array}{l}\text { Rural Population } \\
\qquad(1000)\end{array}$ & $\begin{array}{c}\text { Tractor Number } \\
(1000)\end{array}$ \\
\hline \multirow{3}{*}{$\begin{array}{l}\text { Agricultural Land } \\
\qquad(1000 \mathrm{ha})\end{array}$} & Person Correlation & 1 & $0.801^{* *}$ & $0.447^{*}$ \\
\hline & Sig. (2-tailed) & & 0.000 & 0.015 \\
\hline & $\mathrm{N}$ & 29 & 29 & 29 \\
\hline \multirow{3}{*}{$\begin{array}{l}\text { Rural Population } \\
\qquad(1000)\end{array}$} & Person Correlation & $0.801^{* *}$ & 1 & $0.829^{* *}$ \\
\hline & Sig. (2-tailed) & 0.000 & & 0.000 \\
\hline & $\mathrm{N}$ & 29 & 29 & 29 \\
\hline \multirow{3}{*}{$\begin{array}{l}\text { Tractor Number } \\
\qquad(1000)\end{array}$} & Person Correlation & $0.447^{\star}$ & $0.829^{* *}$ & 1 \\
\hline & Sig. (2-tailed) & 0.015 & 0.000 & 1 \\
\hline & $\mathrm{N}$ & 29 & 29 & 29 \\
\hline
\end{tabular}

**. Correlation is significant at the 0.01 level (2-tailed). *. Correlation is significant at the 0.05 level (2-tailed). 
Similarly, a statistically significant, positive and moderate correlation $(\mathrm{r}=$ 0.447) was found between the agricultural land and the number of tractors during the 1945-1980 period. However, no statistically significant correlation was found between the agricultural land area and the number of tractors in the period of 1980-2017 (Table 5).

Table 5. Correlation analysis in the period 1945 and 2017.

\begin{tabular}{|c|c|c|c|c|}
\hline & & $\begin{array}{l}\text { Agricultural Land } \\
\text { (1000 ha) }\end{array}$ & $\begin{array}{l}\text { Rural Population } \\
(1000)\end{array}$ & $\begin{array}{c}\text { Tractor Number } \\
(1000)\end{array}$ \\
\hline \multirow{3}{*}{$\begin{array}{l}\text { Agricultural Land } \\
\qquad(1000 \mathrm{ha})\end{array}$} & Person Correlation & 1 & $0.749^{\star *}$ & -0.155 \\
\hline & Sig. (2-tailed) & & 0.000 & 0.223 \\
\hline & $\mathrm{N}$ & 64 & 64 & 64 \\
\hline \multirow{3}{*}{$\begin{array}{l}\text { Rural Population } \\
\qquad(1000)\end{array}$} & Person Correlation & $0.749^{\star *}$ & 1 & -0.223 \\
\hline & Sig. (2-tailed) & 0.000 & & 0.076 \\
\hline & $\mathrm{N}$ & 64 & 64 & 64 \\
\hline \multirow{3}{*}{$\begin{array}{l}\text { Tractor Number } \\
\qquad(1000)\end{array}$} & Person Correlation & -0.155 & -0.223 & 1 \\
\hline & Sig. (2-tailed) & 0.223 & 0.076 & \\
\hline & $\mathrm{N}$ & 64 & 64 & 64 \\
\hline
\end{tabular}

*. Correlation is significant at the 0.01 level (2-tailed).

\section{Conclusion and Recommendation}

The people generally benefited from the natural landscape and preferred to use it to obtain maximum benefit. In this context, natural use of land is shaped as forest, pasture, agriculture and other usage areas. However, land use preferences have been changed according to conditions and sectoral needs, rather than natural factors.

While land use change may seem attractive to people and economic sectors in the short term, its devastating effects in the long run cannot be denied. Irreversible losses occur especially in agricultural, forestry and pasture lands. While this change causes the loss of the natural environment, it also endangers food security for many people.

In the correlation analysis, it was determined that the change in the rural population affected agricultural land use. Moreover, a statistically significant, positive and high correlation was found between agricultural areas and rural population during the 1945-2017 period. Land use change in the period 1945-1980 showed that natural forests and grazing lands transformed significantly into cultivated land. However, after 1980, the total cultivated areas started to decrease and according to official statistics, 4.7 million hectares of land were excluded from agriculture until 2017. According to the results of the research examined, the average expansion in residential areas during 1980-2010 was calculated as $161.79 \%$. Since 1945 , the negative impact of the decrease in pasture areas has begun to appear and Turkey has started to import meat after 2010 .

Similarly, in the correlation analysis, a statistically significant, positive and 
moderate correlation was found between the agricultural land and the number of tractors during the 1945-1980 period. However, no statistically significant correlation was found between the land use and the number of tractors after 1980.

Apart from the population and mechanization; legislation is also a factor affecting land use. It is observed that significant increases in production have been achieved with regulations on product basis such as wheat, paddy, sugar beet and cotton. However, it has been observed that pasture, soil protection and hazelnut fields' laws did not provide the expected benefit due to problems arising from implementation.

It is estimated that the impact of artificial factors on land use will gradually increase. In the near future, changes in land use are inevitable depending on sectoral needs. However, this change can be managed by decision-makers in a steady way. For this purpose, land use plans should be prepared in a comprehensive manner taking into account the sectoral needs. In particular, tourism and urban areas should be directed to unproductive lands instead of agricultural, and pasturelands should be protected and enhanced. Then, legal arrangements should be made to ensure compliance with these plans and the Soil Protection Law should be revised taking into account food security. While preparing land use plans, sectoral needs should be considered and land use plans should be secured with legal arrangements.

\section{Acknowledgements}

The author would like thanks to the General Directorate of Agricultural Research, Ministry of Agriculture, and public institutions for providing data provision, and other services during the study periods.

\section{Conflicts of Interest}

The author declares no conflicts of interest regarding the publication of this paper.

\section{References}

Atalay, İ. (2016). A New Approach to the Land Capability Classification: A Case Study of Turkey. Procedia Environmental Sciences, 32, 264-274. https://doi.org/10.1016/j.proenv.2016.03.031

Aysu, A. (2015). Türkiye'nin Toprakla İmtihanı: Bir Mülksüzleştirme Tarihi. Heinrich Böll Stiftung Derneği. https://tr.boell.org/tr

Bell, S., Alves, S., Oliveira, E. S., \& Zuin, A. (2010). Migration and Land Use Change in Europe: A Review. Living Reviews: Landscape Research, 4, 2-49. https://doi.org/10.12942//rlr-2010-2

Bennettab, A., Ravikumarc, A., \& Cronkletona, P. (2018). The Effects of Rural Development Policy on Land Rights Distribution and Land Use Scenarios: The Case of Oil Palm in the Peruvian Amazon. Land Use Policy, 70, 84-93. https://doi.org/10.1016/j.landusepol.2017.10.011

Dengiz, O., \& Turan, İ. D. (2014). Uzaktan Algılama ve Coğrafi Bilgi Sistem Teknikleri 
Kullanılarak Arazi Örtüsü/Arazi Kullanımı Zamansal Değişimin Belirlenmesi: Samsun Merkez İlçesi Örneği (1984-2011). Turkish Journal of Agriculture Research, 1, 78-90. https://doi.org/10.19159/tutad.45474

DSI (2015). State Water Affairs-Devlet Su Isleri Haritalı Istatistik Bülteni. http://www.dsi.gov.tr/docs/yayinlarimiz/2015-harital\%C4\%B1-istatistik-b\%C3\%BClten i.pdf?sfvrsn=2

Ekinci, D., \& Pektezel, Ö. (2012). Uzaktan Algilama Teknolojileri İle Bolu İlinde Arazi Kullanimindaki Değişimin Tespiti. İstanbul Üniversitesi Edebiyat Fakültesi Coğrafya Dergisi, 24, 18-37.

European Commission (2010). Common Agricultural and Bioenergy Policies, Impact on Market and Land Use. https://ec.europa.eu/info/food-farming-fisheries/sustainability/economic-sustainability /bioeconomy/cap-and-bioenergy_en

European Environment Agency (2017). Turkey Landcover 2012 Country Fact Sheet. https://www.eea.europa.eu/themes/landuse/land-cover-country-fact-sheets/tr-turkey-la ndcover-2012.pdf/view

Genç, L., Kızıl, Ü., Arıcı, İ., \& İnalpulat, İ. (2013). Arazi Kullanım ve Bitki Örtüsü Değișiminin Uzaktan Algılama, Markov İşlemi, Nüfus ve Alan Görünüm Analizleri Yardımıyla Belirlenmesi: Çanakkale Örneği (1987-2010). Anadolu Tarım Bilimleri Dergisi, 28, 10-18. https://doi.org/10.7161/anajas.2013.281.10

Grimm, N. B., Chapin, III F. S., Bierwagen, B., Gonzalez, P., Groffman, P. M., Luo, Y., Melton, F., Nadelhoffer, K., Pairis, A., Raymond, P. A., Schimel, J., \& Williamson, C. E. (2013). The Impacts of Climate Change on Ecosystem Structure and Function. Frontiers in Ecology and the Environment, 11, 474-482. https://doi.org/10.1890/120282

Gülersoy, A. E. (2013). Farklı Uzaktan Algılama Teknikleri Kullanılarak Arazi Örtüsü/Kullanımında Meydana Gelen Değişimlerin İncelenmesi: Manisa Merkez İlçesi Örneği (1986-2010). Turkish Studies-International Periodical for the Languages, Literature, and History of Turkish or Turkic, 8, 1915-1934.

https://doi.org/10.7827/TurkishStudies.5232

Gülersoy, A. E. (2014). Seferihisar'da Arazi Kullanımının Zamansal Değișimi (1984-2010) ve İdeal Arazi Kullanımı İçin Öneriler. SDU Faculty of Arts and Sciences Journal of Social Sciences, 31, 155-180.

Göl, C., Özden, S., \& Yılmaz, H. (2011). Interactions between Rural Migration and Land Use Change in the Forest Villages in the Gökçay Watershed. Turkish Journal of Agriculture and Forestry, 35, 247-257.

GTHB (2018). Ministry of Food, Agriculture and Livestock Registers. http://www.tarim.gov.tr

Hoßmann, I., Karsch, M., Klingholz, R., Köhncke, Y., Kröhnert, S., Pietschmann, C., \& Sütterlin, S. (2008). Europe's Demographic Future: Growing Imbalances. Berlin: The Berlin Institute for Population and Development.

Hwang, C. L., \& Kwangsun, Y. (1981). Multiple Attribute Decision Making: Methods and Applications (p. 269). Berlin: Springer. https://doi.org/10.1007/978-3-642-48318-9_3

Kara, F., \& Karatepe, A. (2012). Land Use Change Analysis of Beykoz District (1986-2011) with Remote Sensing Technologies. Marmara Coğrafya Dergisi, 25, 378-389.

Klingebiel, A. A., \& Montgomery, P. H. (1961). Land-Capability Classification. Soil Conservation Service, U.S. Department of Agriculture, Agriculture Handbook No. 210. https://www.nrcs.usda.gov/Internet/FSE_DOCUMENTS/nrcs142p2_052290.pdf 
Liu, B., \& Liu, Z. (2020). The Positive-Externality of Property Right and the Property Right-Regulation: Take the Grain Production-Regulation of Land Use as an Example. Open Journal of Social Sciences, 8, 455-470. https://doi.org/10.4236/jss.2020.83038

Luppa, G., Steinhaußerb, R., Starickc, A., Giesb, M., Bastianb, O., \& Albrechtb, J. (2014). Forcing Germany's Renewable Energy Targets by Increased Energy Crop Production: A Challenge for Regulation to Secure Sustainable Land Use Practices. Land Use Policy, 36, 296-306. https://doi.org/10.1016/j.landusepol.2013.08.012

Marks, M. (1962). Some Effects of Mechanisation on Farmer's Capital. Journal of Agricultural Economics, 15, 296-307. https://doi.org/10.1111/j.1477-9552.1962.tb01717.x

Official Gazette (1937). Forest Law, Numbered 3116.

Official Gazette (1998). Pasture Law, Numbered 4342.

Official Gazette (2005). Law on Soil Protection and Land Use, Numbered 5403.

Official Gazette (2010). Agriculture Basins Regulation, Numbered 27695.

Official Gazette (2017). Decision on the Determination of Some Plains as a Great Plain Conservation Area, Numbered 29955.

Özden, M. O., Keskin, S., Koral, A., Kara, G. Ö., Yazıcı, S., Deveci, G., Öztürk, G., Bostan, P., Özcan, S., Ural, E. C., Eren, Ç., Ünal, A., Atalay, P., \& Bayat, M. (2001). Turkey Soil Information System, General Directorate of Rural Services. Ankara: Soil and Water National Information Centre Report.

Özçağlar, A. (1988). Türkiye’deki Tarım Alanlarının Coğrafi Dağılışının Doğal Çevreyle İlişkisi. A.Ü.D.T.C.F. Coğrafya Araştırmaları Dergisi, 11, 131-150.

Öztürk, M., Topaloğlu, B., Hilton, A., \& Jongerden, J. (2017). Rural-Urban Mobilities in Turkey: Socio-Spatial Perspectives on Migration and Return Movements. Journal of Balkan and Near Eastern Studies, 5, 513-530. https://doi.org/10.1080/19448953.2018.1406696

Passioura, J. B. (1991). Soil Structure and Plant Growth. Journal of Soil Research, 29, 717-728. https://doi.org/10.1071/SR9910717

Prayitno, G., Surjono, S., Hidayat, A. R. T., Subagiyo, A., \& Paramas, N. K. (2018). Factors That Effect to Land Use Change in Pandaan District. IOP Conference Series: Earth and Environmental Science, 202, Article ID: 012006. https://doi.org/10.1088/1755-1315/202/1/012006

Reis, M., Dutal, H., Abız, B., \& Bolat, N. (2016). Kahramanmaraş İli Göksun İlçesi'nde Arazi Kullanımında Meydana Gelen Zamansal Değişimin Uzaktan Algılama Teknikleri ve Coğrafi Bilgi Sistemi İle Belirlenmesi, KSU. Journal of Engineering Sciences, 19, 35-41. https://doi.org/10.17780/ksujes.91496

Salam, A. (1981). Farm Tractorization, Fertilizer Use and Productivity of Mexican Wheat in Pakistan. The Pakistan Development Review, 20, 323-345.

https://doi.org/10.30541/v20i3pp.323-345

Soyaslan, İ. İ., \& Hepdeniz, K. (2016). Coğrafi Bilgi Sistemleri ve Uzaktan Algılama Kullanılarak Burdur İli Arazi Kullanımının Zamansal Değişiminin Belirlenmesi. The Journal of Graduate School of Natural and Applied Sciences of Mehmet Akif Ersoy University, 2, 94-101.

Sykes, M. T. (2009). Climate Change Impacts: Vegetation. In Encyclopedia of Life Sciences (ELS) (pp. 1-11). https://doi.org/10.1002/9780470015902.a0021227

Verburg, P. H., Mertz, O., Erb, K. H., Haberl, H., \& Wu, W. (2013). Land System Change and Food Security: Towards Multi-Scale Land System Solutions. Current Opinion in Environmental Sustainability, 5, 494-502. https://doi.org/10.1016/j.cosust.2013.07.003 
Vodvidicova, B., Ladzianska, Z., \& Peterova, J. (2013). Possibilities of Land Protection against Incorrect Land Use. In 13th International Multidisciplinary Scientific GeoConference SGEM (pp. 1-6). https://www.researchgate.net/publication/269058345 https://doi.org/10.5593/SGEM2013/BE5.V1/S20.099

Turkstat (2018). Turkish Statistical Institute. http://tuik.gov.tr/UstMenu.do?metod=temelist

Yücer, A. A., Demirtas, M., Kan, M., \& Kalanlar, Ş. (2016). The Importance of Creating New Inheritance Policies and Laws That Reduce Agricultural Land Fragmentation and Its Negative Impacts in Turkey. Land Use Policy, 56, 1-7.

https://doi.org/10.1016/j.landusepol.2016.04.029 